\title{
ФОРМУВАННЯ ОБЛІКОВО-АНАЛІТИЧНОГО ЗАБЕЗПЕЧЕННЯ УПРАВЛІННЯ ПРИБУТКОВІСТЮ ПІДПРИЕМСТВ
}

\author{
DOI: 10.32620/cher.2019.2.12
}

\begin{abstract}
Постановка проблеми. Орієнтація на забезпечення сталого розвитку підприємств обумовлює необхідність формування ефективної обліково-аналітичної системи управління прибутковістю. У зв'язку з цим, стаття присвячена розкриттю пріоритетних напрямків розвитку теоретичних та методичних засад щодо формування обліково-аналітичного забезпечення управління прибутковістю. Mema cmammi - розкриття сучасних проблем та пріоритетних напрямків формування обліковоаналітичного забезпечення управління прибутковістю підприємств. Предмет дослідження є теоретичні та методичні положення щодо формування обліково-аналітичної системи в управлінні прибутком підприємств. Об 'єкт дослідження - процес обрання пріоритетів в обліково-аналітичній системі управління прибутковістю підприємств. Методи, використані в дослідженні: наукового пізнання, індукції, системного аналізу та теоретичного узагальнення. Гіпотезою стало припущення, в умовах підвищення фінансової позиції суб'єктів господарювання необхідна переорієнтація обліковоаналітичної системи з метою виявлення впливу чинників на прибуток, резервів і способів їх мобілізації для нарощування прибутковості підприємств. Виклад основного матеріалу. На основі результатів дослідження визначені передумови та проблеми розвитку концептуальних положень обліковоаналітичного забезпечення та окреслено шляхи їх вирішення. Обгрунтовано, що прибуток залежить від вибору методів облікової політики підприємства і процедур оцінки. Доведено, що стратегічний управлінський облік є компонентом обліково-аналітичної системи в управлінні прибутковістю підприємств. Розкрито послідовність формування концепції обліково-аналітичного забезпечення управління прибутковістю підприємств. Оригінальність та практичне значення дослідження полягає в розкритті напрямків розвитку теоретичних та методичних засад формування обліково-аналітичної системи в управлінні прибутковістю підприємств. Висновки дослідження. Впровадження в практику стратегічно орієнтованої обліково-аналітичної системи, надає можливість 3 одного боку оцінити внутрішній потенціал формування прибутковості підприємств, а з іншого - можливості генерування вартості підприємства на майбутнє.
\end{abstract}

\section{Ключові слова:}

обліково-аналітична система, управління прибутковістю, підприємство, облікова політика, резерви, аналіз, стратегічний управлінський облік, стратегія.

\section{FORMATION OF ACCOUNTING AND ANALYTICAL SUPPORT FOR PROFITABILITY MANAGEMENT}

Formulation of the problem. The orientation to sustainable development of enterprises necessitates the formation of effective accounting and analytical system of profitability management. In this regard, the article is focused on the disclosure of priority areas for developing of theoretical and methodological foundations for formation accounting and analytical support for profitability management. The purpose of the research is the disclosure of current problems and priority areas of the formation of accounting and analytical support for the management of profitability of enterprises. The subject of the research is the theoretical and methodological foundations regarding the formation of the accounting and analytical system in the management of the profits of the enterprises. The object of research - the process of selection of priorities of accounting and analytical system in managing the profitability of enterprises. The methods, used in the research are scientific knowledge, induction, system analysis and conceptual synthesis. The hypothesis was assumption, in the conditions of increasing financial position of business entities, it is necessary the reorientation of the accounting and analytical system in order to identify the influence of factors on profits, reserves and ways of their mobilization for increasing the profitability of enterprises. The

${ }^{1}$ Юрченко Олена Сергіївна, завідувач навчально-методичним кабінетом, ДВНЗ «Київський коледж легкої промисловості», м. Київ, Україна.

Yurchenko Olena, Head of the educational-methodical office, Kyiv Polytechnical College of Light Industry, Kyiv, Ukraine.

ORCID ID: 0000-0002-5028-8968

e-mail: elenaurchenko2@gmail.com 
statement of basic materials. Based on the results of the research, the preconditions and problems of the development of the conceptual positions of the accounting and analytical support are determined and the ways of their solution are outlined. It is substantiated that the profit depends on the choice of methods of enterprise accounting policy and assessment procedures. It is proved that strategic management accounting is a component of the accounting and analytical system in managing profitability of enterprises. The sequence of formation of the concept of accounting and analytical support for profitability management of enterprises is disclosed. The originality and practical significance of the research is the disclosure of areas for developing of theoretical and methodical foundations of formation of the accounting and analytical system in the management of profitability of enterprises. Conclusions of the research. Introduction in practice of a strategically oriented accounting and analytical system provides the opportunity to assess the internal capacity of the formation of profitability of enterprises, on the one hand, and, on the other hand, the opportunity of generating the value of the enterprise for the future.reserves

Key words:

accounting and analytical system, profitability management, enterprise, accounting policy, strategic management accounting, reserves, strategy.

\section{ФОРМИРОВАНИЕ УЧЕТНО-АНАЛИТИЧЕСКОГО ОБЕСПЕЧЕНИЯ УПРАВЛЕНИЯ ПРИБЫЛЬНОСТЬЮ ПРЕДПРИЯТИЙ}

Постановка проблемы. Ориентация на обеспечение устойчивого развития предприятий обуславливает необходимость формирования эффективной учетно-аналитической системы управления прибыльностью. В связи с этим, статья посвящена раскрытию приоритетных направлений развития теоретических и методических основ формирования учетно-аналитического обеспечения управления прибыльностью. Цель статьи - раскрытие современных проблем и приоритетных направлений формирования учетно-аналитического обеспечения управления прибыльностью предприятий. Предмет исследования являются теоретические и методические положения по формированию учетноаналитической системы в управлении прибылью предприятий. Объект исследования - процесс избрания приоритетов учетно-аналитической системы в управлении прибыльностью предприятий. Meтоды, использованы в исследовании: научного познания, индукции, системного анализа и теоретического обобщения. Гипотезой стало предположение, в условиях повышения финансовой позиции субъектов хозяйствования необходима переориентация учетно-аналитической системы с целью выявления влияния факторов на прибыль, резервов и способов их мобилизации для наращивания прибыльности предприятий. Изложение основного материала. На основе результатов исследования определены предпосылки и проблемы развития концептуальных положений учетно-аналитического обеспечения и намечены пути их решения. Обосновано, что прибыль зависит от выбора методов учетной политики предприятия и процедур оценки. Доказано, что стратегический управленческий учет является компонентом учетно-аналитической системы в управлении прибыльностью предприятий. Раскрыто последовательность формирования концепции учетно-аналитического обеспечения управления прибыльностью предприятий. Оригинальность и практическое значение исследования заключается в раскрытии направлений развития теоретических и методических основ формирования учетно-аналитической системы в управлении прибыльностью предприятий. Bыводы исследования. Внедрение в практику стратегически ориентированной учетно-аналитической системы, дает возможность с одной стороны оценить внутренний потенциал формирования прибыльности предприятий, а с другой - возможности генерирования стоимости предприятия на будущее.

\section{Ключевые слова:}

учетно-аналитическая система, управление доходностью, предприятие, учетная политика, резервы, анализ, стратегический управленческий учет, стратегия.

Постановка проблеми. Сучасна парадигма формування обліково-аналітичної системи в управлінні прибутковістю повинна бути орієнтована на стратегічне бачення успішності розвитку бізнесу 3 урахуванням оцінки вкладу участі підприємства в економіці. Необхідно акцентувати увагу на взаємозв'язку сукупності компонентів, які формують загальний економічний ефект - ресурси, капітал, заборгованість, доходи та витрати.
Сучасні інформаційні системи управління непристосовані до формування релевантної інформації для здійснення багаторівневого обліку за формуванням прибутку та попереджувального контролю і контролю зі зворотним зв'язком.Підвищення якості інформаційного забезпечення менеджменту підприємства досягається за рахунок комплексного використання облікової і аналітичної складових. Управлінська інформація повинна бути 
сформована в контексті задоволення вимог ключових зацікавлених сторін і релевантна поставленим цілям і завданням бізнесу. Тому удосконалення обліково-аналітичної системи стає необхідною умовою виявлення впливу чинників на прибуток, резервів і способів їх мобілізації для нарощування прибутковості підприємства.

Аналіз останніх досліджень i публікацій. Теоретичні основи обліку фінансових результатів розкриті у наукових працях вітчизняних вчених, серед яких: Орлова В. К. [12], Панченко I. А. [13], Прохар Н. В. [17], Скрипник М. С. [18] та зарубіжних вчених: Бернстайн Л. А. [4], К. Друрі [5], Хорнгрен Ч. Т. [19].

Методики аналізу та аналітичний інструментарій управління прибутковістю висвітлено у наукових працях вітчизняних вчених, зокрема: Антонюк О. О. [1], Бабіч В. В. [2], Білик М. Д. [5], Лахтіонова Л.А. [8], Лебедєва А. М. [9], Підгірна В. С. [15], Турило А. М. [18], Фролова Л. В. [19].

Ряд питань щодо формування обліковоаналітичної системи в управлінні прибутковістю підприємств потребують подальших досліджень,зокрема класифікація індикаторів прибутковості залежно від потреб користувачів та менеджменту; облік і аналіз витрат і доходів за видами діяльності; узагальнення та модифікація обліково-аналітичної інформації для оцінювання резервів прибутковості та потенціалу створення вартості 'єктів господарювання.

Мета статті. Розкриття сучасних проблем та пріоритетних напрямків формування обліково-аналітичного забезпечення прибутковістю підприємств.

Виклад основного матеріалу дослідження. Фінансовий результат вважається індикатором результативності діяльності та ефективності управління, джерелом подальшого розвитку підприємств. Він є складним об'єктом обліку i аналізу, що вимагає постійного вдосконалення підходів до визначення та оцінки фінансових результатів діяльності підприємств. Сучасні теорії бухгалтерського обліку оріснтують на автономне або інтегроване ведення обліку в різних підсистемах: фінансового, податкового та управлінського обліку. Результати дослідження свідчать про наявність ряду проблем пов язаних 3 організацією обліковоаналітичної системи управління прибутковістю підприємств, які потребують вирішення
Перша група проблем пов язана 3 формуванням облікової інформації щодо прибуткості 3 урахуванням інтересів користувачів. Існує велика кількість индикаторов оцінки прибутковості , які впливають на методичне забезпечення обліку і отримання якісної інформації для прийняття управлінських рішень. Виходячи 3 цього, індикатори прибутковості слід класифікувати наступним чином: 1) відносно підприємства: індикатори для зовнішніх та внутрішніх користувачів; 2) залежно від цілей і задач користувачів: індикатори призначені для вищої ланки, підрозділів, власників, економістів, бухгалтерів, інвесторів, кредиторів; 3) по відношенню до звітності: індикатори звітності і розраховункові на основі даних звітності; 4) за станом: статичні і динамічні; 5) залежно від терміну часу: ретроспективні, прогнозні; 6) за джерелами інформації: індикатори фінансової, управлінської і податкової звітності. Використання такої класифікації індикаторів надає можливість формувати інформацію щодо оцінки фінансового результату для потреб користувачів звітності та визначати напрямки поточного та стратегічного контролю, а також здійснювати аналіз для прийняття управлінських рішень та прогнозування прибутковосTi.

Друга група проблем пов'язана 3 підвищенням якості обліку і аналізу фінансових результатів господарюючих суб'єктів. Фінансові результати займають центральне місце в системі показників, що використовуються для аналізу ефективності діяльності підприємств. Прибуток - це абсолютний показник, який розраховується як різниця між доходами і витратами і відображає фінансовий результат діяльності підприємства. За таких умов прибуток в поточному періоді не відображає можливість отримання його в майбутньому та зростання капіталу або вартості підприємства.

В умовах інфляції та невизначеності відтворення капіталу в ринковій економіці не завжди достатньо ресурсів, які тотожні наявним ресурсам попереднього періоду.Тому приріст капіталу це більш об'єктивний показник, що характеризує ефективність діяльності підприсмства. Для отримання достовірної інформаціі щодо взаємозв язку прибутку i капіталу підприємства необхідно формування раціональної облікової політики. Застосування різних варіантів облікової політики дозволяє маніпулювати фінансовими показниками, що 
призводить до невідповідності показників фінансової звітності, створення можливостей приховування фінансового результату, та необ'єктивного відображення на рахунках бухгалтерського обліку. Тому необхідним при визначенні облікової політики дотримуватися принципів бухгалтерського обліку,зокрема принципу обачливості.У П(с)БО 11 «Зобов'язання» та МСБО 37 «Забезпечення, умовні зобов’язання та умовні активи» законодавчо закріплено дотримання принципу обачності при оцінці наслідків непередбачених зобов язань і розкритті відповідної інформації в бухгалтерській звітності підприємства. Такий принцип проявляється на етапі створення резервів на покриття витрат ймовірних для даного або майбутніх звітних періодів, тобто реєстрацію передбачуваних або ймовірних фактів господарського життя. Створення на підприємстві резервів здійснюється незалежно від наявності прибутку. На необхідність створення резерву відпусток вказують П. 13 П(С)БО 11 та П. 7 П(С)БО 26. Забезпечення створюються для відшкодування наступних (майбутніх) операційних витрат на: виплату відпусток працівникам; додаткове пенсійне забезпечення; виконання гарантійних зобов'язань;реструктуризацію, виконання зобов'язань при припиненні діяльності; виконання зобов'язань щодо обтяжливих контрактів тощо. (п. 13 П(С)БО 11). Виплати за невідпрацьований час, що підлягають накопиченню, визнаються зобов'язанням через створення забезпечення у звітному періоді. (п. 7 П(С)БО 26) Мета створення резервів, $€$ страхування підприємства від майбутніх витрат, та мінімізації ризику, визнання обов'язковими майбутніх витрат в поточному звітному періоді. Тому при виборі облікової політики підприємства необхідно враховувати те, що прибуток залежить від вибору методів і процедур оцінки.

Третя проблема - необхідність переорієнтації обліково-аналітичної ситеми на інформаційне забезпечення стратегічного управління. Така система повинна бути спрямована на формування облікової і аналітичної інформації для дослідження стратегічних аспектів розвитку наявних i передбачуваних можливостей створення вартості підприємства. Стратегічний управлінський облік повинен бути центральним елементом обліково-аналітичної системи який виконує три підфункції. По-перше, це підфункція стратегічного аналізу, реалізація якої проявляється в процесі розробки та коригування стратегії. По-друге, облікова підфункція підтримки управлінських рішень. Ця функція проявляється на етапі проведення аналізу окремих видів діяльності, а також участі в формуванні інформації для розробки операційних бюджетів. для здійснення аналізу розвитку підприємства, дослідження фактичних і планових показників, відображення стратегї в системі конкретних фінансових показників підприємства в цілому i його окремих підрозділів. найбільш придатною є збалансована система показників

По-третє, підфукція, стратегічного управлінського обліку ,реалізується у формі довгострокової фінансової моделі та розкриває прогнозні макроекономічні і ринкові показники, стратегіï, дії конкурентів. Вона охоплює не тільки фінансові, а й не фінансові показники ( наприклад, економічна додана вартість підприємства EVA), а також комплексні показники, тобто всі показники, які є необхідними для розробки, коригування та оцінки реалізації стратегії підприємства [5, с. 132]. Таким чином, інформація стратегічного управлінського обліку надає можливість здійснити аналіз впливу факторів зовнішнього середовища на прийняття стратегічних рішень підприємства.

Наступною функцією $є$ аналітична функція стратегічного управлінського обліку, реалізація якої здійснюється на основі інструментів оцінки створення вартості підприємства. На підставі даних стратегічного управлінського обліку здійснюється SWOT-аналіз зовнішнього i внутрішнього середовища підприємства, результати якого $є$ основою для визначення чинників, що впливають на фінансовий стан та розвиток господарюючого суб'єкта.

Четверта проблема - розвиток методологічних засад обліково-аналітичного забезпечення управління прибутковістю підприємств в контексті реалізації фінансової концепції. Послідовність розробки концепції обліковоаналітичної системи забезпечення прибутковості підприємств наведена на рис. 1. Розвиток методології обліково-аналітичного забезпечення прибутковості підприємства розглядається 3 позиції реалізації концепцій: фінансової, ланцюжка цінностей, ризик- менеджменту, збалансованості інтересів зацікавлених сторін.

Методологічним базисом обліковоаналітичної системи є полідисциплінарний підхід, системний підхід, сценарний підхід, об'єктно-орієнтований підхід, теорії стратегічного управлінського обліку та вартіснооріентованого менеджменту. Облік i аналіз прибутковості базується на принципах співвідношення інформації з прийняттям рішень, гнучкості, альтернативності, ризик- менеджменту. 
Мета дослідження -удосконалення організаційно-методичного забезпечення обліковоаналітичної системи управління прибутковістю підприємств в контексті реалізації фінансової концепції

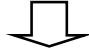

Методологія дослідження: полідисциплінарний підхід, системний підхід, сценарний підхід, об’єктно-орієнтований підхід, теорії стратегічного управлінського обліку та вартісно-

орієнтованого менеджменту

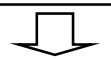

Основні напрями дослідження - стратегічний управлінський облік та аналіз витрат та доходів підприємств: світова практика й вітчизняний досвід, методичні підходи до аналізу резервів прибутковості підприємств; методичні підходи до оцінювання втрат економічних вигід від ризиків бізнесу.

Очікувані результати - формування концепції обліково-аналітичного забезпечення прибутковості підприємств, побудова уточненої системи показників рентабельності в контексті нівелювання відмінностей у формуванні фінансових результатів і грошових потоків; розробка методичного підходу до багаторівневого аналізу прибутковості підприємства; розробка моделі факторного аналізу ефективності з урахуванням ризику бізнесу; побудова прогнозних моделей рентабельності діяльності підприємств

Рис. 1. Послідовність розробки концепції обліково-аналітичної системи в управлінні прибутковістю підприємств Джерело: розроблено автором

Реалізація принципу співвідношення облікової інформації з прийняттям рішень означає: формування системи управлінської звітності залежить від специфіки підприємства; вибір структури показників, способів групування і модифікації облікової інформації залежно від цілей і завдань відповідного рівня менеджменту.

Принцип гнучкості означає забезпечення аналітичності управлінського обліку, тобто формування релевантної інформації для швидкого реагування на зміни факторів що впливають на результативність діяльності бізнес -одиниць та підприємства. Цей принцип слід розглядати через призму формування розподілу і використання прибутку підприємств в умовах змін господарювання підприємств. За наявності змін структура обліково-аналітичної інформації може бути переглянута.

Принцип альтернативності передбачає, що формування інформації залежить від облікової політики та вибору обліковоаналітичного інструментарію. На облікову політику впливають методи оцінки активів, довгострокових фінансових інвестицій, розподілу витрат на продукцію, нарахування амортизації. Підгрунтям реалізації цього принципу є сценарне мислення щодо прийняття управлінських рішень та вибору альтернатив стратегії розвитку підприємства.
Принцип ризик-менеджменту проявляється на етапі формування превентивної інформації для оцінювання впливу фінансових ризиків на прибутковість підприємства та прогнозування ймовірності їх виникнення на майбутнє. Такими ризиками можуть бути: ризик знецінення фінансових вкладень, непогашення дебіторської заборгованості, неплатоспроможність.

Виходячи $з$ потреб користувачів інформації, аналіз прибутковості, як самостійний компонент обліково-аналітичної системи повинен бути сфокусований, по-перше, на взаємозв'язку сукупності показників, які впливають на ефективність підприємства: ресурси, капітал, заборгованість, доходи та витрати; по-друге на успішності розвитку бізнесу 3 урахуванням вкладу підприємства в економіку регіону і країни в цілому.

Комплексний аналіз базується на інтеграції системи показників рентабельності капіталу, діяльності, грошових потоків та модифікації індикаторів прибутковості з урахуванням ризиків, що дозволяє сформувати інформацію для багаторівневої аналітичної оцінки прибутковості і прогнозування ефективності діяльності підприємства. Результати такого аналізу є основою для здійснення порівняльного аналізу ефективності з аналогами бізнесу і прийняття рішень 
щодо підвищення прибутковості підприємства та інвестування розвитку підприємства.

Висновки i перспективи подалыших досліджень. Обліково-аналітична система в управлінні прибутковістю переорієнтована на стратегію розвитку бізнесу та багатоваріантність формування релевантної інформації дозволяє оцінити резерви прибутковості та приймати управлінські рішення щодо підвищення ефективності діяльності підприємств. Запропонована послідовність формування концепції обліково-аналітичного забезпечення управління прибутковістю підприємств на новій парадигмі розкриває складові їі методологічних та методичних засад. Впровадження методики багаторівневого аналізу прибутковості підприємств на підставі системи показників рентабельності грошових потоків і діяльності підприємств надає можливість здійснювати порівняльний аналіз ефективності діяльності суб'єктів господарювання, та розробляти заходи щодо інвестування їх розвитку.

Подальші дослідження полягають у розкритті методологічних та методичних положень 3 організації обліково-аналітичної системи в управління прибутковістю суб’єктів господарювання.

\section{Література}

1. Антонюк О. О. Оцінка рівня прибутковості як важлива складова діагностики кризових явищ підприємства / Вісник «ХНУ». Економічні науки. - 2013. - № 5. - Т. 2. - С. 20-24.

2. Бабіч В. В. Удосконалення обліку формування, розподілу й використання прибутку / В. В. Бабіч, А. М. Поддєрьогін // Фінанси України. - 2012. - № 2. - С. 103-110.

3. Балічька В. В. Рентабельність діяльності суб'єктів господарювання України: оцінювання істинних результатів / В. В. Баліцька // Актуальні проблеми економіки. - 2012. - № 11. - C. 120-130.

4. Бернстайн Л. А. Анализ финансовой отчетности: теория, практика и интерпретация / Л. А. Бернстайн: пер. с англ. / под ред. чл.-корр. РАН И. И. Елисеева; гл. редак. серии проф. Я. В. Соколов. - М.: Финансы и статистика, 2003. $-624 \mathrm{c}$.

5. Білик М. Д. Фінансові результати діяльності малих підприємств: оцінка та прогнозування: монографія / М. Д. Білик, Т. О. Білик. Київ: ТОВ «ПанТот», 2012. - 280 с.

6. Друри К. Управленческий и производственный учет: / К. Друри: пер. с англ. - М.: ЮНИТИ-ДАНА, 2003. - 1071 с.

7. Костирко Р. О. Система внутрішнього контролю резервів потенціалу прибутковості: методологія, організація, методичне забезпечення / Р. О. Костирко // Вісник Східноукраїнського національного університету імені Володимира Даля. - 2008. - Ч. 2. - № 10 (128).- С. 92-103.

8. Лахтіонова Л. А. Фінансовий аналіз суб'єктів господарювання: монографія / Л. А. Лахтіонова. - К.: КНЕУ, 2001. - 387 с.

9. Лебедєва A. М. Методичні аспекти аналізу рентабельності діяльності підприємства / А. М. Лебедєва // Вісник ОНУ імені I.I. Мечникова. - 2012. Т. 17 Вип. 3-4. - С. 29-36.

10. Михайлова Н. В. Дискусійні підходи до розподілу прибутку підприємств / Н. В. Михайлова // Науковий вісник Полтавського університету економіки і торгівлі. - 2014. - № 2(64). - С. 59-63.

11. Національне положення (стандарт) бухгалтерського обліку 1 «Загальні вимоги до фінансової звітності»: затв. Наказом Міністерства фінансів України: від 07.02.2013 р. № 73 [Електронний ресурс]. - Режим доступу: http://zakon4.rada.gov.ua/laws/show/z0336-13.

12. Орлова B. K. Використаний / розподілений. Оцінка достовірності інформації щодо нерозподіленого прибутку в балансі / В. К. Корпан // Аудитор України. - 2010. - № 7 (179) - C. 48-51.

13. Панченко I. A. Класифікація прибутку для цілей бухгалтерського обліку, аналізу та контролю: критичний аналіз існуючих підходів / I. А. Панченко // Вісник ЖДТУ. Економічні науки. - 2012. - Вип. 1 (22) - С. 224-236.

14. Положення (стандарт) бухгалтерського обліку 16 «Витрати», затв. Наказом Міністерства фінансів України від 31.12.1999 № 318 [Електронний ресурс]. - Режим доступу: http://zakon2.rada.gov.ua/laws/show/z0027-00.

15. Підгірна B. C. Теоретикометодологічні засади формування прибутку суб'єктів господарювання / В. С. Підгірна // Збірник наукових праць Львівського національного університету імені Івана Франка «Формування ринкової економіки в Україні», 2013. № 29, Ч.2. - С. 77-84.

16. Скрипник M. С. Облік і аналіз фінансових результатів в управлінні виробничим підприємством : автореф. дис. ... канд. екон. наук / М. Є. Скрипник. - К., 2014. - 23 с.

17. Прохар H. В. Облік доходів, витрат і фінансових результатів: проблеми теорії та практики: монографія / Н. В. Прохар, Ю. О. Ночовна. -Полтава: РВВ ПУЕТ, 2011. $257 \mathrm{c}$.

18. Турило A. М. Фінансово-економічні аспекти оцінки результатів і ефективності діяльності підприємства / А. М. Турило, О. А. Зін- 
ченко // Фінанси України. - К., 2008. - № 8. - С. $35-44$.

19. Фролова Л. В. Діагностика фінансових результатів діяльності підприємства / Л.В. Фролова, М.С. Травкіна // Торгівля і ринок України: зб. темат. наук. пр. Вип. 31. Т. 1 / Голов. ред. О. О. Шубін. - Донецьк: ДонНУЕТ, 2011. C. $350-355$.

20. Хорнгрен Ч. Т. Бухгалтерский учет: управленческий аспект / Ч. Т. Хорнгрен. Дж. Фостер: пер. с англ.; под ред. Я. В. Соколова. - М.: Финансы и статистика, 2005. -416 с.

\section{References}

1. Antonyuk, O. O. (2013). Estimation of the level of profitability as an important component of the diagnosis of crisis phenomena of the enterprise. Economic Sciences, 5, 2, 20-24.

2. Babich, V. V. \& Podderyogin, A. M. (2012). Improvement of accounting for the formation, distribution and use of pritbot. Finances of Ukraine, 2, 103-110.

3. Balitskaya, V. V. (2012). Profitability of business entities in Ukraine: evaluation of true results. Current problems of the economy, 11, 120-130.

4. Bernstein, L. A. (2003). Analysis of Financial Statements: Theory, Practice and Interpretation. Moscow: Finance and Statistics, 624.

5. Bilyk, M. D. \& Bilyk, T. O. (2012). Financial Results of Small Businesses: Estimation and Forecasting. Monograph. Kyiv: "PanTot LLC", 280.

6. Drury, K. (2003). Management and production accounting. Moscow: UNITI-DANA, 1071.

7. Kostyrko, R. O. (2008). System of internal control of reserves of potential for profit: methodology, organization, methodical support. Bulletin of the East-Ukrainian National University named after Volodymyr Dahl, 2, 10 (128), 92-103.

8. Lakhtionova, L. A. (2001). Financial analysis of subjects of management: monograph. Kyiv: KNEU, 387.

9. Lebedeva, A. M. (2012). Methodological aspects of enterprise profitability analysis. Bulletin of the Mechnikov ONU, 17, 3-4, 29-36.

10. Mikhailova, N. V. (2014). Discussion approaches to the distribution of profits of enter-

\footnotetext{
Стаття надійшла

до редакції : 05.05.2019 p.
}

prises. Scientific Bulletin of the Poltava University of Economics and Trade, 2(64), 59-63.

11. National Accounting Standards (Standard) 1 "General Requirements for Financial Statements": Zat. By order of the Ministry of Finance of Ukraine: from 07.02.2013 № 73. Retreived from : http://zakon4.rada.gov.ua/laws/show/z0336-13.

12. Orlov V.K. Used / Distributed. Validation of information on undistributed profits in the Balance / VK Corpan // Auditor of Ukraine. - 2010. - No. 7 (179) - p. 48-51.

13. Panchenko I.A. Classification of profit for accounting, analysis and control purposes: a critical analysis of existing approaches / I.A. Panchenko // Journal of ZHDTU. Economic Sciences. - 2012. - Exp. 1 (22) - P. 224-236.

14. Regulation (standard) of accounting for accounting 16 "Expenses", pos. By order of the Ministry of Finance of Ukraine dated December 31, 1999, № 318: Retreived from: http://zakon2.rada.gov.ua/laws/show/z0027-00.

15. Pidhirna, V. C. (2013). Theoretical and methodological principles of profit generation of economic entities. Collection of scientific works of the Ivan Franko National University of Lviv "Formation of a market economy in Ukraine", 29, 2, 77-84.

16. Skrypnyk, M. E. (2014). Accounting and analysis of financial results in the production management of the enterprise: author's abstract. dis ... Candidate econ Sciences. Kyiv, 23.

17. Prokhar, N. V. (2011). Accounting for income, expenses and financial results: problems of theory and practice: monograph. Poltava: RVV PUET, 257.

18. Turilo, A. M. \& Zinchenko, O. A. (2008). Financial and economic aspects of estimation of results and efficiency of enterprise activity. Finances of Ukraine, 8, 35-44.

19. Frolova, L. V. \& Travkin, M. S. (2011). Diagnostics of financial results of the enterprise activity. Trade and Rick-Ukraine of Ukraine. Donetsk: Don-NOUT, 350-355.

20. Horngrin, Ch. T. (2005). Accounting: Management Aspect. Moscow: Finance and Statistics, 416.

\section{Стаття прийнята \\ до друку: 26.06.2019 p.}

Бібліографічний опис для цитування :

Юрченко О. С. Формування обліково-аналітичного забезпечення управління прибутковістю підприємств / О. С. Юрченко // Часопис економічних реформ. - 2019. - № 2 (34). - С. 103 -109 . 